\title{
Effects of Halogenated Compounds on in vitro Fermentation Characteristics in the Rumen and Methane Emissions
}

\author{
Hee Soon Hwang', Ji Un OK², Shin Ja Lee, Gyo Moon Chu, kyoung Hoon Kim², Young Kyoon Oh², \\ Sang Suk Lee ${ }^{5}$ and Sung Sill Lee * \\ ${ }^{1}$ Division of Applied Life Science (BK21 program), Institute of Agriculture and Life Science, Gyeongsang National University, Jinju 660-701, \\ Korea \\ ${ }^{2}$ Animal Nutrition Team, National Institute of Animal Science, RDA, Suwon 441-706, Korea \\ ${ }^{3}$ Department of Animal Science, Gyeongbuk Provincial College, Yeacheon 757-807, Korea \\ ${ }^{4}$ Swine Science \& Technology Center, Gyeangnam National University of Science and Technology, Jinju 757-807, Korea \\ ${ }^{5}$ Department of Animal Science \& Biotechndogy, Sunchon National University, Sunchon 540-742, Korea
}

Received June 1, 2012 /Revised August 2, 2012 /Accepted August 7, 2012

\begin{abstract}
This study was conducted to evaluate effects of halogenated compounds on in vitro rumen fermentation characteristics and methane emissions. A fistulated Holstein cow of $650 \mathrm{~kg}$ body weight was used as a donor of rumen fluid. Five kinds of halogenated compounds (bromochloromethane (BCM), 2-bromoethane sulfonic acid (BES), 3-bromopropanesulfonic acid (BPS), chloroform (CLF), and pyromellitic diimide (PMDI) known to inhibit methyl-coenzyme $\mathrm{M}$ reductase activity were added to an in vitro fermentation incubated with rumen fluid. The microbial population including bacteria, protozoa, and fungi were enumerated, and gas production including methane and fermentation characteristics were observed in vitro. The $\mathrm{pH}$ values ranged from 6.25 to 6.72 in all the treatments, and these showed a similar level at $48 \mathrm{hr}$. The total gas production in the treatments showed a similar pattern with $\mathrm{C}$ at $48 \mathrm{hr}$, whereas methane production in the treatments was lower $(p<0.05)$ than $\mathrm{C}$. Concentrations of total volatile fatty acids (VFAs) and propionic acid were higher $(p<0.05)$ in the treatments than in $\mathrm{C}$ at $12 \mathrm{hr}$. Therefore, halogenated compounds (BCM, BES, BPS, CLF, and PMDI) inhibited in vitro methane emissions by inhibiting methanogens in the rumen. Further studies on safety are needed.
\end{abstract}

Key words : Dry matter degradation, halogenated compounds, methane emission, methyl-coenzyme $\mathrm{M}$ reductase, ruminal fermentation

\section{서 론}

반추동물이 방출하는 메탄의 양은 지구에서 발생되는 메탄 의 약 23 27\%를 차지하며, 연간 발생량은 약 81 92만 톤으로 추정하고 있다. 메탄이 지구온난화에 미치는 영향은 이산화탄 소보다 약 21 배 높아 지구온난화를 일으키는 가장 중요한 원 인이다[17,34]. 메탄은 섭취한 사료 중의 영양소가 반추위 내 미생물 발효에 의해 대사에너지로 전환되면서 발생하는데, 이 는 2 15\% 정도의 사료 이용 에너지 손실을 가져온다[24]. 현재 까지 반추동물에서 발생되는 메탄의 양을 줄이기 위해 유기산 류[22], 불포화지방산[35], 식물추출물[15] 및 할로겐 화합물 [14] 등을 이용한 연구가 활발히 진행되고 있다.

특히 할로겐 화합물 중 2-bromoethane sulfonic acid (BES) 를 이용하여 methanogen과 공생하는 반추위 내의 protozoa를 억제 하고자 하였는데, 반추위 내의 bacteria 나 protozoa에는 영향을 미치지 않았다[3,26,27,28,36]. 반면, BES는 metha-

*Corresponding author

Tel : +82-55-772-1883, Fax : +82-55-772-1889

E-mail : 1ss@gnu.ac.kr nogen에 존재하는 coenzyme $\mathrm{M}$ 의 구조적 유사체로 메탄 생성 에 관여하는 methyl-coenzyme M reductase의 활력을 억제시 켜 메탄 발생량을 감소시키고[4], 또한 chloroform (CLF)이 반 추위 내 메탄생성을 억제한다는 연구 결과를 통해 $[2,5,8$, 19,20,31] methyl-coenzyme M reductase를 억제함으로써 반 추위 내 메탄 발생량을 저감할 수 있다고 보고 되었다[28].

본 연구는 bromochloromethane (BCM), 2-bromoethane sulfonic acid (BES), 3-bromopropanesulfonic acid (BPS), chloroform (CLF) 및 pyromellitic diimide (PMDI)의 할로겐 화합물이 반추위 내 발효와 메탄가스 발생에 미치는 영향을 알아보고자 하였다.

\section{재료 및 방법}

\section{공시동물 및 반추위액}

반추위액은 순천대학교 부속농장(순천시 서면 지본리 375 번지)의 반추위 cannula가 시술된 24개월령 체중 $650 \mathrm{~kg}$ 의 홀 스타인으로부터 채취하였다. 공시동물에 Italian rye grass와 배합사료를 $6: 4$ 의 비율로 체중의 $3 \%$ 수준으로 1 일 2회 분할 
(06:00 시, 16:00 시) 급여하였고, 물과 미네랄은 자유 섭취토록 하였다. 반추위액은 09:00 시에 반추위 cannula를 통하여 반추 위액을 채취한 후 4 겹의 cheese cloth로 여과하였고, 채취한 위액은 혐기상태로 유지 된 21 의 유리병에 담아 실험실로 이 동하여 in vitro 시험에 사용하였다.

\section{공시시료 및 in vitro 배양}

공시시료는 $70^{\circ} \mathrm{C}$ 의 건조기에서 24 시간 건조시킨 timothy를 $2 \mathrm{~mm}$ 스크린으로 분쇄하여 기질로 이용하였고, timothy의 화학조성은 $10.77 \%$ 수분, $6.35 \%$ 조단백질, $2.00 \%$ 조지방, $25.83 \%$ 조섬유 및 $6.68 \%$ 조회분을 함유하였다. 본 실험에서는 $\mathrm{BCM}, \mathrm{BES}, \mathrm{BPS}, \mathrm{CLF}$ 및 PMDI 할로겐 화합물(Sigma Chemical Co., St. Louis, Mo, USA)을 사용하였다. 혐기상태로 $0.3 \mathrm{~g}$ timothy가 기질로 들어 있는 $60 \mathrm{ml}$ serum bottle에 10 $\mathrm{ml} \mathrm{McDougall} \mathrm{buffer}$ 와 $5 \mathrm{ml}$ 위액을 분주하고(대조구; C), $\mathrm{BCM}$ (BCM구), $\mathrm{BES}$ (BES구), $\mathrm{BPS}$ (BPS구), $\mathrm{CLF}$ (CLF구) 및 $\mathrm{PMDI}$ (PMDI구) 5종의 할로겐 화합물 처리구에 각각 $1 \mathrm{ppm}$ 씩 첨가한 후, 고무마개로 막고 알루미늄으로 sealing 하였다. 기질은 $39^{\circ} \mathrm{C}$ 의 shaking incubator (120 rpm; SI-900R, Jeio Tech, Korea)에서 3, 6, 12, 24, 36 및 48 시간 배양 후 시료를 채취하여 분석하였다. 실험은 6처리 3반복으로 시험을 수행하 였다.

\section{조사항목 및 방법}

$\mathrm{pH}$ 는 $\mathrm{pH}$ meter (MP230, Mettler Toledo, Switzerland)를 이용하여 측정하였다. 건물 소화율은 Moore [19]의 방법을 이 용하였고, Filter paper (Watman. No. 1, GE Healthcare companies, UK)를 이용하여 배양물 내 기질만을 거른 후 $70^{\circ} \mathrm{C}$ dry oven에서 24시간 건조시킨 후 측정하였다. 혐기성 bacteria와 fungi 수 측정은 Chu 등[6]의 방법에 따라 실시 하였으 며, bacteria 수는 Dehority's artificial medium [9]를 이용하였 으며, roll tube 방법[16]으로 혐기배양 후 colony 수를 측정하 였다. Fungi는 Lowe's media [21]에 배양시킨 후, thallus 생성 수를 측정하였다. 험기성 protozoa의 living cell과 dead cell을

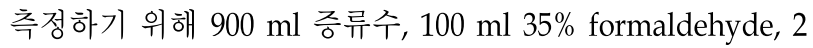
$\mathrm{g}$ trypan blue, $8 \mathrm{~g} \mathrm{NaCl}$ 으로 구성된 TBFS (trypan blue- formalin-salin) 용액으로 living cell의 핵을 염색한 후 Abe 등[1] 의 방법에 따라 plankton counter glass를 이용하여 현미경으 로 측정하였다. 총 가스발생량은 Fedorah와 Hrudey [12]의 방법에 따라 water displacement apparatus를 이용하여 측정 하였다.

메탄가스 분석은 총 가스 발생량 측정 후 $4 \mathrm{ml}$ 의 가스를 vaccutainer에 채취하여 Porapak NQ column (Q 80-100 mesh)이 장착된 Gas Chromatography (GC; GC-2010; Shimadzu, Japan)를 이용하여 분석하였다. GC의 조건은 oven temperature $80^{\circ} \mathrm{C}$, injector temperature $100^{\circ} \mathrm{C}$, FID (Flame ionization detector) temperature $110^{\circ} \mathrm{C}$ 로 하였으며, total running time은 3 분이었고, carrier gas는 헬륨과 수소가스를 함께 이용하였다.

휘발성 지방산은 $\mathrm{pH}$ 및 총 가스발생량을 측정 한 후의 반추 위 배양물의 상층액을 취하여 high performance liquid chromatography (HPLC; Agilent Technolgies 1200 series, Agilent, Germany)를 이용하여 분석하였다. Lactic acid 분석 의 detector는 UV/Visible detector (Agilent Technolgies 1200 series, Germany)를 사용하고, $210 \mathrm{~nm}$ 및 $220 \mathrm{~nm}$ 의 파장에서 분석을 하였다. MetaCard $87 \mathrm{H}(300 \mathrm{~mm} \times 7.8 \mathrm{~mm}$; Varian, Germany) 칼럼을 사용하였고, 칼럼의 사용온도는 $35^{\circ} \mathrm{C}$, total running time은 30 분이었다.

\section{통계처리}

본 시험에서 얻은 결과들은 SAS program [29]의 General Linear Model (GLM) procedure를 이용하여 분산분석을 하였 고, Duncan's multiple range test [11]을 이용하여 $p<0.05$ 의 수준으로 유의성을 검증하였다.

\section{결과 및 고찰}

\section{$\mathrm{pH}$ 의 변화}

할로겐 화합물의 첨가가 in vitro 상의 $\mathrm{pH}$ 변화에 미치는 영향은 Table 1 과 같다. 모든 처리구의 $\mathrm{pH}$ 값은 6.25 에서 6.72 정도의 범위로 배양시간이 경과함에 따라 낮아지는 경 향을 보였고, 배양 48 시간 후에서의 $\mathrm{pH}$ 는 대조구와 처리구 간 유의적인 차이는 나타나지 않았지만, 배양 36 시간까지의 $\mathrm{pH}$ 는 다른구에 비해 $\mathrm{BCM}$ 구에서 유의적 $(\beta<0.05)$ 으로 낮았으 며, 또한 배양 5 시간까지의 $\mathrm{pH}$ 는 대조구에 비해 처리구에서 낮았다. in vitro 상에서의 $\mathrm{pH}$ 변화는 반추위 내 배양 기간이 길어짐에 따라 미생물의 성장 및 탄수화물 분해 작용에 의해 휘발성지방산의 발생량 증가 및 당의 생성량이 증가되기 때 문이며, 본 연구의 결과도 할로겐 화합물이 미생물의 성장에 영향을 주지 않아 배양 기간이 길어짐에 따라 $\mathrm{pH}$ 가 감소한 것으로 생각된다.

\section{건물 소화율}

할로겐 화합물의 첨가가 in vitro 상의 건물 소화율에 미치는 영향을 Table 2에 나타내었다. 배양 12 시간 후부터는 할로겐 화합물의 첨가가 건물 소화율에는 영향을 주지 않았다. 이러 한 결과는 BES가 기질의 소화율에는 영향을 주지 않았고, 메 탄 발생량을 감소시켰다는 Dong 등[10]의 보고와 일치하였고, Goel 등[14]은 BCM 첨가가 기질의 소화율에 영향을 미치지 않았지만, Sawyer 등[30]은 양에게 $\mathrm{BCM}$ 을 급여하여 건물 소 화율이 증가하였다고 보고하였다. 따라서 본 연구에서는 할로 겐 화합물이 미생물의 성장 억제에 영향을 주지 않았기 때문 
Table 1. Effects of halogenated compounds on in vitro $\mathrm{pH}$ value

\begin{tabular}{clllllll}
\hline \multirow{2}{*}{ Incubation (hr) } & \multicolumn{9}{c}{ Treatment } & \multirow{2}{*}{ SEM $^{1}$} \\
\cline { 2 - 6 } & $\mathrm{C}$ & $\mathrm{BCM}$ & $\mathrm{BES}$ & $\mathrm{BPS}$ & CLF & PMDI $^{\mathrm{ab}}$ & \\
\hline 3 & $6.71^{\mathrm{ab}}$ & $6.67^{\mathrm{b}}$ & $6.68^{\mathrm{ab}}$ & $6.72^{\mathrm{a}}$ & $6.69^{\mathrm{ab}}$ & $6.70^{\mathrm{ab}}$ & 0.02 \\
6 & $6.70^{\mathrm{a}}$ & $6.66^{\mathrm{b}}$ & $6.68^{\mathrm{ab}}$ & $6.68^{\mathrm{ab}}$ & $6.66^{\mathrm{b}}$ & $6.66^{\mathrm{b}}$ & 0.01 \\
12 & $6.65^{\mathrm{ab}}$ & $6.63^{\mathrm{b}}$ & $6.66^{\mathrm{a}}$ & $6.67^{\mathrm{a}}$ & $6.64^{\mathrm{ab}}$ & $6.64^{\mathrm{ab}}$ & 0.01 \\
24 & $6.55^{\mathrm{ab}}$ & $6.49^{\mathrm{b}}$ & $6.53^{\mathrm{abc}}$ & $6.51^{\mathrm{bc}}$ & $6.51^{\mathrm{bc}}$ & $6.57^{\mathrm{bc}}$ & 0.02 \\
36 & $6.38^{\mathrm{bc}}$ & $6.34^{\mathrm{c}}$ & $6.45^{\mathrm{a}}$ & $6.37^{\mathrm{bc}}$ & $6.36^{\mathrm{c}}$ & $6.44^{\mathrm{ab}}$ & 0.11 \\
48 & $6.26^{\mathrm{a}}$ & $6.28^{\mathrm{a}}$ & $6.25^{\mathrm{a}}$ & $6.28^{\mathrm{a}}$ & $6.28^{\mathrm{a}}$ & $6.34^{\mathrm{a}}$ & 0.12 \\
\hline
\end{tabular}

C, control; BCM, bromochloromethane; BES, 2-bromoethanesulfonic acid; BPS,

3-bromopropanesulfonic acid; CLF, chloroform; PMDI, pyromellitic diimide

${ }^{1}$ Standard error of the mean

${ }^{a, b, c}$ Means in the same row with different superscripts differ at $p<0.05$.

Table 2. Effects of halogenated compounds on the in vitro dry matter disappearance (\%)

\begin{tabular}{cccccccc}
\hline \multirow{2}{*}{ Incubation $(\mathrm{hr})$} & \multicolumn{9}{c}{ Treatment } & \multirow{2}{*}{ SEM $^{1}$} \\
\cline { 2 - 6 } & $\mathrm{C}$ & BCM & BES & BPS & CLF & PMDI & \\
\hline 3 & $11.30^{\mathrm{ab}}$ & $6.17^{\mathrm{ab}}$ & $1.70^{\mathrm{ab}}$ & $7.52^{\mathrm{ab}}$ & $13.20^{\mathrm{a}}$ & $9.01^{\mathrm{ab}}$ & 4.01 \\
6 & $11.58^{\mathrm{a}}$ & $8.74^{\mathrm{ab}}$ & $3.45^{\mathrm{b}}$ & $11.84^{\mathrm{a}}$ & $7.02^{\mathrm{ab}}$ & $13.84^{\mathrm{a}}$ & 3.51 \\
12 & $14.35^{\mathrm{a}}$ & $11.71^{\mathrm{a}}$ & $12.33^{\mathrm{a}}$ & $13.07^{\mathrm{a}}$ & $11.49^{\mathrm{a}}$ & $11.74^{\mathrm{a}}$ & 3.10 \\
24 & $22.94^{\mathrm{a}}$ & $24.25^{\mathrm{a}}$ & $22.82^{\mathrm{a}}$ & $21.99^{\mathrm{a}}$ & $27.65^{\mathrm{a}}$ & $14.55^{\mathrm{b}}$ & 2.97 \\
36 & $37.50^{\mathrm{a}}$ & $35.74^{\mathrm{a}}$ & $36.30^{\mathrm{a}}$ & $37.81^{\mathrm{a}}$ & $37.09^{\mathrm{a}}$ & $33.84^{\mathrm{a}}$ & 2.59 \\
48 & $37.85^{\mathrm{a}}$ & $34.91^{\mathrm{a}}$ & $40.42^{\mathrm{a}}$ & $41.05^{\mathrm{a}}$ & $40.70^{\mathrm{a}}$ & $34.98^{\mathrm{a}}$ & 6.22 \\
\hline
\end{tabular}

C, control; BCM, bromochloromethane; BES, 2-bromoethanesulfonic acid; BPS, 3-bromopropanesulfonic acid; CLF, chloroform; PMDI, pyromellitic diimide

${ }^{1}$ Standard error of the mean

a,b Means in the same row with different superscripts differ at $p<0.05$.

Table 3. Effects of halogenated compounds on the in vitro ruminal microbe diversity after $12 \mathrm{hr}$ incubation

\begin{tabular}{|c|c|c|c|c|c|c|}
\hline \multirow{2}{*}{ Population of anaerobic microflora } & \multicolumn{6}{|c|}{ Treatment } \\
\hline & $\mathrm{C}$ & BCM & BES & BPS & CLF & PMDI \\
\hline Bacteria, $\mathrm{cfu}^{1)} \times 10^{7}$ & $6.33 \pm 1.20^{b}$ & $9.33 \pm 1.76^{b}$ & $15.33 \pm 1.86^{\mathrm{a}}$ & $6.33 \pm 0.67^{b}$ & $17.33 \pm 2.96^{\mathrm{a}}$ & $7.33 \pm 1.20^{b}$ \\
\hline \multicolumn{7}{|l|}{ Protozoa, cell $\times 10^{3}$} \\
\hline Live cell & $15.75 \pm 2.50^{\mathrm{a}}$ & $10.50 \pm 1.76^{\mathrm{a}}$ & $14.50 \pm 2.47^{\mathrm{a}}$ & $11.00 \pm 1.83^{\mathrm{a}}$ & $13.25 \pm 2.14^{\mathrm{a}}$ & $9.75 \pm 1.11^{\mathrm{a}}$ \\
\hline Dead cell & $2.00 \pm 0.71^{\mathrm{b}}$ & $2.50 \pm 0.65^{\mathrm{ab}}$ & $4.75 \pm 1.49^{\mathrm{a}}$ & $1.75 \pm 0.63^{b}$ & $1.75 \pm 0.25^{\mathrm{b}}$ & $1.75 \pm 0.63^{b}$ \\
\hline Fungi, $\mathrm{cfu} \times 10^{2}$ & $12.00 \pm 2.89^{b}$ & $22.66 \pm 1.76^{\mathrm{ab}}$ & $17.00 \pm 5.51^{\mathrm{ab}}$ & $33.67 \pm 6.74^{a}$ & $17.33 \pm 7.54^{\mathrm{ab}}$ & $23.33 \pm 7.36^{\mathrm{ab}}$ \\
\hline
\end{tabular}

C, control; BCM, bromochloromethane; BES, 2-bromoethanesulfonic acid; BPS, 3-bromopropanesulfonic acid; CLF, chloroform; PMDI, pyromellitic diimide

Mean \pm standard error

${ }^{a, b}$ Means in the same row with different superscripts differ at $p<0.05$.

에 영양소 소화율에는 영향 미치지 않는 것으로 생각된다.

\section{혐기성 미생물 수 변화}

할로겐 화합물의 첨가가 in vitro 상에서의 혐기성 미생물 수의 변화에 미치는 영향은 Table 3과 같다. 혐기성 bacteria의 수는 대조구에 비해 BPS구를 제외한 처리구에서 많은 경향을 보였고, 특히 BES구 및 $\mathrm{CLF}$ 구가 다른구에 비해 유의적 ( $p<0.05)$ 으로 많았다. Methanogen과 밀접한 연관이 있는 생존 하고 있는(live) protozoa의 수는 대조구에 비해 처리구에서 감소되었으며, 혐기성 fungi의 수는 대조구에 비해 처리구에
서 유의적 $(p<0.05)$ 으로 증가하였다.

반추위 내의 protozoa는 Methanobrevibacter ruminantium, Methanobacterium formicicum 그리고 Methanomicrobium mobile 등과 같은 methanogens와 공생관계에 있고, 반추위 내에서 생성되는 메탄 중 $37 \%$ 를 차지하고[6], 할로겐 화합물은 methanogen에 직접적인 독성을 가하여 메탄생성을 억제시키 는 물질로서, 이는 methanogen에 의해 메탄 생성의 최종단계 에서 이용되는 Methyl-coenzyme M reductase의 활동을 억제 함으로써 메탄생성을 감소시키는 것으로 알려져 있다[4]. Goel 등[14]은 $\mathrm{BCM}$ 의 첨가가 methanogens를 감소시켜 메탄 
Table 4. Effects of halogenated compounds on total gas and methane emission in in vitro

\begin{tabular}{cccccccc}
\hline \multirow{2}{*}{ Incubation $(\mathrm{hr})$} & \multicolumn{9}{c}{ Treatment } & \multirow{2}{*}{ SEM $^{1}$} \\
\cline { 2 - 5 } Total gas, $\mathrm{ml} / \mathrm{g}$ & $\mathrm{C}$ & BCM & BES & BPS & CLF & PMDI \\
3 & $5.23^{\mathrm{b}}$ & $6.13^{\mathrm{a}}$ & $6.07^{\mathrm{a}}$ & $4.17^{\mathrm{c}}$ & $5.63^{\mathrm{ab}}$ & $4.17^{\mathrm{c}}$ & 0.41 \\
6 & $6.83^{\mathrm{a}}$ & $6.97^{\mathrm{a}}$ & $7.10^{\mathrm{a}}$ & $7.23^{\mathrm{a}}$ & $6.77^{\mathrm{a}}$ & $6.03^{\mathrm{b}}$ & 0.34 \\
12 & $10.57^{\mathrm{a}}$ & $10.30^{\mathrm{a}}$ & $10.07^{\mathrm{a}}$ & $9.63^{\mathrm{a}}$ & $9.40^{\mathrm{a}}$ & $9.70^{\mathrm{a}}$ & 0.98 \\
24 & $16.73^{\mathrm{abc}}$ & $17.17^{\mathrm{ab}}$ & $16.30^{\mathrm{bc}}$ & $18.00^{\mathrm{a}}$ & $16.60^{\mathrm{abc}}$ & $15.27^{\mathrm{c}}$ & 0.84 \\
36 & $20.97^{\mathrm{bc}}$ & $22.23^{\mathrm{a}}$ & $17.70^{\mathrm{e}}$ & $21.50^{\mathrm{ab}}$ & $20.50^{\mathrm{c}}$ & $19.40^{\mathrm{d}}$ & 0.97 \\
48 & $24.30^{\mathrm{a}}$ & $22.70^{\mathrm{a}}$ & $24.10^{\mathrm{a}}$ & $24.30^{\mathrm{a}}$ & $22.17^{\mathrm{a}}$ & $23.20^{\mathrm{a}}$ & 3.35 \\
\hline Methane, mMol/g & & & & & & \\
3 & $1.63^{\mathrm{a}}$ & $0.60^{\mathrm{b}}$ & $1.87^{\mathrm{a}}$ & $1.67^{\mathrm{a}}$ & $0.85^{\mathrm{b}}$ & $0.50^{\mathrm{b}}$ & 0.37 \\
6 & $2.95^{\mathrm{b}}$ & $0.44^{\mathrm{c}}$ & $2.49^{\mathrm{b}}$ & $4.17^{\mathrm{a}}$ & $0.44^{\mathrm{c}}$ & $0.43^{\mathrm{c}}$ & 0.46 \\
24 & $3.73^{\mathrm{a}}$ & $0.27^{\mathrm{d}}$ & $0.69^{\mathrm{c}}$ & $2.47^{\mathrm{b}}$ & $0.33^{\mathrm{d}}$ & $0.27^{\mathrm{d}}$ & 0.19 \\
36 & $5.98^{\mathrm{b}}$ & $0.2^{\mathrm{d}}$ & $0.75^{\mathrm{c}}$ & $7.08^{\mathrm{a}}$ & $0.31^{\mathrm{d}}$ & $0.23^{\mathrm{d}}$ & 0.24 \\
48 & $7.87^{\mathrm{a}}$ & $0.16^{\mathrm{c}}$ & $2.99^{\mathrm{b}}$ & $8.74^{\mathrm{a}}$ & $0.21^{\mathrm{c}}$ & $0.19^{\mathrm{c}}$ & 0.88 \\
\hline
\end{tabular}

C, control; BCM, bromochloromethane; BES, 2-bromoethanesulfonic acid; BPS, 3-bromopropanesulfonic acid; CLF, chloroform; PMDI, pyromellitic diimide

${ }^{1}$ Standard error of the mean

a,b,c,d Means in the same row with different superscripts differ at $p<0.05$.

생성을 억제 하지만, 혐기성 bacteria 및 protozoa의 수에는 영향을 미치지 않으며, fungi의 수는 증가하였다고 하였다.

본 연구의 결과 할로겐 화합물의 첨가는 반추위 내 메탄생 성을 억제 시키지만, 혐기성 protozoa 수에는 영향을 미치지 않는 것으로 보여 혐기성 protozoa 수와 메탄 발생량 간에는 상관관계가 없었다는 Goel 등[14]의 결과와 일치하였으며, 본 연구의 결과, 할로겐 화합물이 반추위 내의 혐기성 미생물의 수에는 영향을 미치지 않았다.

\section{총 가스 및 메탄 발생량}

할로겐 화합물이 총 가스 발생량 및 메탄 발생량에 미치는 영향은 Table 4 와 같다. 배양 48 시간까지 총 가스 발생량은 처리구간 차이는 없었다. 배양 6시간부터의 메탄 발생량은 $\mathrm{BPS}$ 구를 제외한 모든 처리구가 대조구에 비해 유의적( $\beta<0.05)$ 으로 감소하였고, 특히 배양 48시간의 메탄 발생량은 CLF구 및 $\mathrm{BCM}$ 구가 다른구에 비해 유의적( $p<0.05)$ 으로 낮았다.

본 연구에서 보여진 할로겐 화합물이 메탄 발생량을 감 소시킨다는 결과는 BPS 첨가가 메탄 발생량에는 영향을 미 치지 않는다는 Ungerfeld 등[33]의 보고와 일치하였고, 본 실험에 사용한 BPS 이외의 할로겐 화합물은 반추위 내의 메 탄 발생량을 감소시켰다 $[7,18,32]$. 본 실험의 결과, $\mathrm{BCM}$ 첨 가는 반추위 내의 메탄 발생량을 감소시켰고, 이는 면양에 게 $\mathrm{BCM}$ 을 급여하였을 때 메탄 발생량이 감소한다는 Sawyer 등[30]의 보고 및 소에서 cyclodextrin과 $\mathrm{BCM}$ 을 혼 합 급여하면 메탄 발생량이 감소한다는 $\mathrm{McCrabb}$ 등[23]의 보고와 유사하였다. 배양 12 시간에서의 메탄 발생량은 BES 구가 대조구에 비해 유의적( $p<0.05)$ 으로 낮았는데, Balch와
Wolfe [4]는 BES가 coenzyme M의 유사체로서, 메탄생성 과정에서 methyl-coenzyme $\mathrm{M}$ reductase 활동을 억제하여 메탄 발생량을 감소시킨다고 하였다.

본 연구의 결과 총 가스 발생량은 대조구와 유의적인 차이 가 없지만, 메탄 발생량은 대조구에 비해 배양 12 시간부터 $\mathrm{BPS}$ 구를 제외한 모든 처리구에서 유의적 $(p<0.05)$ 으로 낮았다. 따라서 할로겐 화합물의 첨가는 in vitro 상에서의 반추위 발효 성상에는 큰 영향을 미치지 않아 총 가스 발생량에는 영향을 주지 않으며 메탄 발생량을 감소시켰다.

\section{휘발성 지방산 및 젖산 생성량}

할로겐 화합물의 첨가가 배양 3 시간 및 12 시간의 휘발성지 방산 및 젖산생성에 미치는 영향은 Table 5 와 같다. 할로겐 화합물의 첨가는 대조구에 비해 총 휘발성 지방산 및 propionic acid의 발생량을 유의적으로 증가시켰다( $p \ll 0.05)$. 또한, butyric acid의 발생량은 처리구간 유의적인 차이는 없지만, $\mathrm{BCM}$ 구 및 $\mathrm{BPS}$ 구에서 높았으며, lactic acid의 발생량 또한 $\mathrm{BPS}$ 구가 다른구에 비해 유의적( $p<0.05)$ 으로 높았다. Goel 등 [14]은 $\mathrm{BCM}$ 을 첨가는 in vitro 상에서 총 휘발성 지방산의 생성 에 영향을 주지 않으면서 메탄 발생량을 감소시킨다고 하였 고, Dong 등[10] 또한 BES의 첨가가 총 휘발성 지방산 발생량 에는 영향을 주지 않으면서 메탄 발생량을 $71 \%$ 정도 감소시킨 다고 하였다. 본 실험의 결과에서도 할로겐 화합물의 첨가는 반추위 발효성상에는 영향을 미치지 않으면서 메탄생성을 억 제시켰다. BPS 첨가는 메탄 발생량에는 영향을 주지 않았지만 가스 발생량, 혐기성 미생물의 수 및 건물 소화율을 증가시키 는 것으로 보아 사료의 소화율이 가장 높게 나타나 in vitro 
Table 5. Effects of halogenated compounds on ruminal fermentation characteristics after $3 \mathrm{hr}$ and $12 \mathrm{hr}$ incubation (ppm)

\begin{tabular}{|c|c|c|c|c|c|c|c|c|}
\hline \multirow{2}{*}{\multicolumn{2}{|c|}{ Incubation (hr) }} & \multicolumn{6}{|c|}{ Treatment } & \multirow{2}{*}{ SEM $^{1}$} \\
\hline & & $\mathrm{C}$ & $\mathrm{BCM}$ & BES & BPS & CLF & PMDI & \\
\hline \multirow{5}{*}{3} & Total VFA & $2,119^{a}$ & $3,848^{\mathrm{a}}$ & $5,094^{\mathrm{a}}$ & $1,888^{\mathrm{a}}$ & $2,313^{\mathrm{a}}$ & $2,744^{\mathrm{a}}$ & 1242.88 \\
\hline & Acetic acid & $525^{\mathrm{a}}$ & $1,379^{\mathrm{a}}$ & $542^{\mathrm{a}}$ & $763^{\mathrm{a}}$ & $873^{\mathrm{a}}$ & $1,095^{\mathrm{a}}$ & 379.32 \\
\hline & Propionic acid & $884^{\mathrm{ac}}$ & $1,238^{\mathrm{a}}$ & $1,166^{\mathrm{a}}$ & $615^{\mathrm{a}}$ & $772^{\mathrm{a}}$ & $936^{\mathrm{a}}$ & 353.48 \\
\hline & Butyric acid & $710^{\mathrm{b}}$ & $1,231^{b}$ & $4,196^{\mathrm{a}}$ & $510^{b}$ & $668^{b}$ & $713^{b}$ & 1121.39 \\
\hline & Lactic acid & $2,551^{\mathrm{a}}$ & $3,521^{\mathrm{a}}$ & $2,526^{\mathrm{a}}$ & $2,268^{\mathrm{a}}$ & $2,955^{\mathrm{a}}$ & $3,100^{\mathrm{a}}$ & 781.38 \\
\hline \multirow{4}{*}{12} & Total VFA & $1,403^{\mathrm{c}}$ & $3,330^{\mathrm{abc}}$ & $2,007^{\mathrm{bc}}$ & $5,148^{\mathrm{a}}$ & 2,681 & $3,228^{a b}$ & 859.20 \\
\hline & Propionic acid & $927^{c}$ & $1,265^{\mathrm{bc}}$ & $1,283^{\mathrm{bc}}$ & $3,104^{a}$ & $1,687^{\mathrm{bc}}$ & $2,025^{b}$ & 357.57 \\
\hline & Butyric acid & $476^{\mathrm{a}}$ & $2,067^{\mathrm{a}}$ & $724^{\mathrm{a}}$ & $2,044^{\mathrm{a}}$ & $994^{\mathrm{a}}$ & $1,203^{\mathrm{a}}$ & 710.01 \\
\hline & Lactic acid & $3,127^{b}$ & $3,738^{\mathrm{ab}}$ & $3,891^{\mathrm{ab}}$ & $5,826^{\mathrm{a}}$ & $4,150^{\mathrm{ab}}$ & $5,747^{\mathrm{a}}$ & 944.88 \\
\hline
\end{tabular}

C, control; BCM, bromochloromethane; BES, 2-bromoethanesulfonic acid; BPS, 3-bromopropanesulfonic acid; CLF, chloroform; PMDI, pyromellitic diimide

${ }^{1}$ Standard error of the mean

$a, b, c$ Means in the same row with different superscripts differ at $p<0.05$.

상의 propionic acid의 발생량을 높이는 것으로 생각된다.

이상의 실험 결과를 종합해 보면, 할로겐 화합물 첨가는 반 추위 내 $\mathrm{pH}$, 가스 발생량, 반추위 미생물 성장량 및 propionic acid 모두 증가하였으며, 반추위내 메탄생성을 억제하였다. 앞 으로 할로겐화합물과 다른 메탄억제 물질과 혼합하여 반추위 내 메탄생성 억제에 관한 구체적인 연구가 필요한 것으로 생 각된다.

\section{감사의 글}

본 연구는 농림수산식품기술평가원(IPET) 농림수산식품연 구개발 지정공모과제의 지원과 경상대학교 농업생명과학연 구원(IALS) 및 BK21농생명산업 글로벌인재 육성사업단의 지 원을 받았습니다.

\section{References}

1. Abe, M., Shibui, H. and Kumeno, F. 1972. Improved method for counting rumen protozoa. Jap. J. Zootech. Sci. 43,535.

2. Achtnich, C., Bak, F. and Conrad, R. 1995. Competition for electron donors among nitrate reducers, ferric iron reducers, sulfate reducers, and methanogens in anoxic paddy soil. Biol. Fertil. Soils 19, 65-72.

3. Alperin, M. J. and Reedurgh, W. S. 1985. Inhibition experiments on anaerobic methance oxidation. Appl. Environ. Microbiol. 50, 940-945.

4. Balch, W. D. and Wolfe, R. S. 1979. Specificity and biological distribution of coenzyme M (2-mercaptoethane sulfonic acid). J. Bacteriol. 137, 256-263.

5. Chin, K. J. and Conrad, R. 1995. Intermediary metabolism in methanogenic paddy soil and the influence of temperature. FEMS Microbiol. Ecol. 18, 85-102.

6. Chu, G. M., Lee, S. J., Jeong, H. S. and Lee, S. S. 2011. Efficacy of probiotics from anaerobic microflora with pre- biotics on growth performance and noxious gas emission in growing pigs. Anim J. Sci. 82, 282-290.

7. Czerkawski, J. W., Christie, W. W., Breckenridge, G. and Hunter, M. L. 1975. Changes in the rumen metabolism of sheep given increasing amounts of linseed oil in their diet. Br. J. Nutr. 34, 25-44.

8. DeGraaf, W., Wellsbury, P., Parkes, R. J. and Cappenberg, T. E. 1996. Comparison of acetic acid turnover in methanogenic and sulfate-reducing sediments by radiolabeling and stable isotope labeling and by use of specific inhibitors: evidence for isotopic exchange. Appl. Environ. Microbiol. 62, 772-777.

9. Dehority, B. A. and Scott, H. W. 1967. Extent of cellulose and hemicellulose digestion in various forage by pure cultures of rumen bacteria. J. Dairy Sci. 50, 1136-1141.

10. Dong, Y., Bae, H. D., McAllister, T. A., Mathison, G. W. and Cheng, K. J. 1997. Lipid-induced depression of methane production and digestibility in the artificial rumen system (RUSITEC). Can. J. Anim Sci. 77, 269-278.

11. Duncan, D. B. 1995. Multiple range and multiple $F$ test. Biometrics 11, 1-6.

12. Fedorah, P. M. and Hrudey, S. E. 1983. A simple apparatus for measuring gas production by methanogenic cultures in serum bottles. Environ. Tech Lett. 4, 268.

13. Finlay, B. J., Esteban, G., Clarke, Ken J., Williams, Alan G., MartinEmbley, T. and Hirt, R. R. 1994. Some rumen ciliates have endosymbiotic methanogens. FEMS Microbiol. Lett. 117, 157-162.

14. Goel, G., Makkar, H. P. S. and Becker, K. 2009. Inhibition of methanogens by bromochloromethane: effects on microbial communities and rumen fermentation using batch and continuous fermentations. Br. J. Nutr. 101, 1484-1492.

15. Hart, K. J., Yanez-ruiz, D. R., Duval, S. M., McEwan, N. R. and Newbold, C. J. 2008. Plant extract to manipulate rumen fermentation. Anim Feed Sci. Technol. 147, 8-35.

16. Hungate, R. E. 1966. The rumen and it's microbes. pp. 92-446, Academic press, NY.

17. IPCC (Intergovernmental Panel on Climate Change). 1992. 
Climate Change 1992. The supplementary report to the IPCC Scientific Assessment. pp. 200, In Houghton, J. T., Callander, B. A. and Varney, S. K. (eds.), Cambridge University Press, Cambridge, UK.

18. Johnson, E. D., Wood, A. S., Stone, J. B. and Moran, E. T. 1972. Some effects of methane inhibition in ruminants (steers). Can. J. Anim Sci. 52, 703-712.

19. Jones, J. G. and Simon, B. M. 1985. Interaction of acetogens and methanogens in anaerobic freshwater sediments. Appl. Environ. Microbiol. 49, 944-948.

20. Lovely, D. R. and Klug, M. J. 1982. Intermediary metabolism of organic matter in the sediments of a eutrophic lake. Appl. Environ. Microbiol. 43,552-560.

21. Lowe, S. E., Theodorou, M. K., Trinci, A. P. J. and Hespell, R. B. 1985. Growth of anaerobic rumen fungi on defined and semi-defined media lacking rumen fluid. J. Gen. Microbiol. 131, 2225-2229.

22. Martin, S. A. 1998. Manipulation of ruminal fermentation with organic acids: a review. J. Anim Sci. 76, 3123-3132.

23. McCrabb, G. J., Berger, K. T., Magner, T., May, C. and Hunter, R. A. 1997. Inhibiting methane production in Brahman cattle by dietary supplementation with a novel compound and the effects of growth. Aust. J. Agric. Res. 48, 323-329.

24. Moss, A. R., Jouany, J. P. and Newbold, J. 2000. Methane production by ruminants: Its contribution to global warming. Ann. Zootech 49, 231-253.

25. Moore, J. E. 1970. Procedure for two-stage in vitro digestion of forage. In Harrison, S. E. (ed.). Nutrition research technique for domestic and wild animals. Utah State Univ., Logan, UT. USA

26. Nollet, L., Demeyer, D. and Verstraete, W. 1997. Effect of 2-bromo- ethanesulfonic acid and Peptostreptococcum productus ATCC 35244 addition on stimulation of reductive acetogenesis in the ruminal ecosystem by selective inhibition of methanogenesis. Appl. Environ. Microbiol. 63,
194-200.

27. Nozoe, T. 1997. Effects of methanogenesis and sulfate-reduction on acetogenetic oxidation of propionic acid and further decomposition of acetic acid in paddy soil. Soil Sci. Plant Nut. 43,1-10.

28. Oremland, R. S. and Capone, D. G. 1988. Use of 'specific' inhibitors in biogeochemistry and microbial ecology. $A d V$. Microb. Ecol. 10, 285-383.

29. SAS. 1996. SAS User Guide. Release 6.12 edition. SAS Inst. Inc. Cary NC. USA.

30. Sawyer, M. S., Hoover, W. H. and Sniffen, C. J. 1974. Effects of a ruminal methane inhibitor on growth and energy metabolism in the ovine. J. Anim Sci. 38, 908-914.

31. Thebrath, B., Mayer, H. P. and Conrad, R. 1992. Bicarbonatedependent production and methanogenic consumption of acetic acid in anoxic paddy soil. FEMS Microbiol. Ecol. 86, 295-302.

32. Trei, J. E., Parish, R. C. and Singh, Y. K. 1971. Effect of methane inhibitors on rumen metabolism and feedlot performance of sheep. J. Dairy Sci. 54, 536-540.

33. Ungerfeld, E. M., Rust, S. R., Jain, M. K. and Burnett, R. 2002. Some miscellaneous inhibitors of rumen methanogenesis in vitro. In Beef Cattle, Sheep and Forage Systems. Research and Demonstration Report 581, 113-122. East Lansing, MI: Michigan State University.

34. Wuebbles, D. J. and Hayhoe, K. 2002. Atmospheric methane and global change. Earth-Sci. Rev. 57, 177-210.

35. Zhang, C. M., Guoa, Y. Q., Yuan, Z. P., Wu, Y. M., Wang, J. K., Liu, J. X. and Zhub, W. Y. 2008. Effect of octadeca carbon fatty acids on microbial fermentation, methanogenesis and microbial flora in vitro. Anim Feed Sci. Technol. 146, 259-269.

36. Zinder, S. H., Anguish, T. and Cardwell, S. C. 1984. Selective inhibition by 2-bromoethanesulfonate of methanogenesis from acetic acid in a thermophilic anaerobic digestor. Appl. Environ. Microbiol. 47, 1343-1345. 


\section{초록 : 할로겐 화합물의 첨가가 반추위 발효성상과 메탄생성에 미치는 영향}

황희순 ${ }^{1} \cdot$ 옥지운 ${ }^{2}$ 이신자 ${ }^{3} \cdot$ 추교문 $^{4} \cdot$ 김경훈 $^{2} \cdot$ 오영균 $^{2} \cdot$ 이상석 ${ }^{5} \cdot$ 이성실 $^{1}{ }^{\star}$

(경상대학교 응용생명과학부(BK21 program) \& 농업생명과학연구원, ${ }^{2}$ 농촌진흥청 국립축산과학원 영양생 리팀, ${ }^{3}$ 경북도립대학 축산과, ${ }^{4}$ 경남과학기술대학교 양돈과학기술센터, ${ }^{5}$ 순천대학교 동물자원과학과)

본 연구는 할로겐 화합물의 첨가가 in vitro 상의 반추위 발효성상과 메탄생성에 미치는 영향에 대한 효과를 규명하고자 실시하였다. Italian rye grass 및 배합사료를 6:4의 비율로 급여한 반추위 cannula가 시술된 홀스타인 에서 반추위액을 채취하여 사용하였고, 채취된 반추위액은 분쇄된 timothy (대조구; C)에 bromochloromethane (BCM구), 2-Bromoethanesulfonic acid (BES구), 3-Bromopropanesulfonic acid (BPS구), chloroform (CLF구) 및 Pyromellitic diimide (PMDI구)의 5가지 할로겐 화합물을 각각 $1 \mathrm{ppm}$ 씩 첨가하여 in vitro 배양하였다. $\mathrm{pH}$ 는 6.72 에서 6.25 정도로 배양시간이 경과함에 따라 낮아지는 경향을 나타내었고, 배양 48 시간에는 처리구간 차이가 없 었다. 배양 48 시간 후의 총 가스 발생량은 처리구간 유의적인 $(p<0.05)$ 차이는 없었고, BPS구를 제외한 모든 처리 구 에서의 메탄 발생량은 대조구에 비해 유의적으로 $(p<0.05)$ 감소하였다. 배양 12 시간에서의 총 휘발성 지방산 및 propionic acid의 발생량은 처리구가 대조구에 비해 유의적으로 $(p<0.05)$ 높았다. 본 실험의 결과, 할로겐 화합 물의 첨가는 반추위 내의 $\mathrm{pH}$, 건물 소화율, 미생물 수 및 총 가스 발생량의 발효 성상에는 영향을 주지 않으면서 메탄의 발생량이 감소 되었다. 실험 결과를 종합해 보면, 할로겐 화합물 첨가는 반추위 내 $\mathrm{pH}$, 가스 발생량, 반추 위 미생물 성장량 및 propionic acid 모두 증가하였으며, 반추위내 메탄생성을 억제하였다. 앞으로 할로겐화합물 과 다른 메탄억제 물질과 혼합하여 반추위 내 메탄생성 억제에 관한 구체적인 연구가 필요한 것으로 생각된다. 